Part of Journal of Research of the National Bureau of Standards, Volume 19, October 1937

\title{
SEPARATION OF THE THREE METHYLOCTANES FROM MIDCONTINENT PETROLEUM ${ }^{1}$
}

\author{
By Joseph D. White ${ }^{2}$ and Augustus R. Glasgow, Jr. ${ }^{2}$
}

\section{ABSTRACT}

The complex methyloctane fraction of an Oklahoma petroleum has been successfully separated into its constituent hydrocarbons. The isolation of three of its seven components, 2-, 3-, and 4-methyloctane, by alternating distillation with extraction and crystallization is described. The three, in the order named, are present in petroleum in the proportion of 3,1 , and 1 ; the total methyloctane content of the crude oil being about 0.3 percent.

The boiling point, freezing point, density, refractive index, and critical solution temperature in aniline have been determined for each compound.

\section{CONTENTS}

I. Introduction

II. Procedure.

1. Preliminary fractionation

2. Isolation of 2-methyloctane $\ldots \ldots \ldots$

3. Isolation of 3-methyloctane

4. Isolation of 4-methyloctane

III. Properties of the isolated compounds

IV. Content of the methyloctanes in the petroleum

V. References .

\section{INTRODUCTION}

The presence of the methyloctane fraction in an Oklahoma petroleum ${ }^{3}$ became apparent when, a few years ago, the material boiling normally between 140 and $145^{\circ} \mathrm{C}$ was redistilled after first removing the aromatic hydrocarbons by extraction [1]. ${ }^{4}$ More recently, Tongberg, Fenske, and Nickels [2] have encountered the same fraction in petroleum from the Yates field in Texas. Besides $o$-xylene, which was extracted, not less than six hydrocarbons are present in the fraction from Oklahoma petroleum, namely, two naphthenes and four isomeric nonanes. It is not surprising, thererore, to find so little recorded concerning the composition of the corresponding fractions in other petroleums.

Separation of the methyloctane fraction into its constituent hydrocarbons is not an easy task. There is no record that it has been done previously. To carry out the separation successfully has required the judicious use of distillation, extraction, absorption, and crystallization, with the aid of modern and efficient fractionating equipment.

1 Financial assistance has been received from the research fund of the American Petroleum Institute. This work is part of Project 6, The Separation, Identification, and Determination of the Ccnstituents of Petroleum. This paper was presented before the American Chemical Society meeting in Rochester, September 1937.

2 Research Associate at the National Bureau of Standards, representing the American Petroleum Institute.

$3 \mathrm{~A}$ description of the oil is given in BS J. Research 2, 469, table 1 (1929) RP45, and in J. Research NBS

15, 212 (1935) RP824.

Numbers in brackets throughout the tert indicate references listed at the end of the paper. 


\section{PROCEDURE}

\section{PRELIMINARY FRACTIONATION}

After extracting the xylenes with liquid sulphur dioxide, the material was systematically distilled at a pressure of $215 \mathrm{~mm}$ through a 30-plate column equipped with bubbling caps. Results of the distillation are shown in figure 1 . The lower graph gives the volume of distillation fractions boiling successively in intervals of $0.5^{\circ} \mathrm{C}$. In all, nearly 17 liters (representing 2,250 liters of crude oil) distilled within the range 98 to $104^{\circ} \mathrm{C}$, which corresponds approximately to 140.5 to $146^{\circ} \mathrm{C}$ at normal pressure. The upper graph of unshaded lines shows the refractive index ${ }^{5}$ of each half-degree fraction of distillate. The range in index indicates, in the absence of more than small amounts of aromatic hydrocarbons, that the distillate was composed of a mixture of some of the nonanaphthenes and isononanes known to boil in this region of temperature.

Nitration tests indicated that on the average the material contained about 2 mole percent of aromatic hydrocarbons. To free the distillate from these constituents, all fractions boiling between 98 and $103.5^{\circ} \mathrm{C}$ were filtered through columns of silica gel. The procedure has been described elsewhere [3]. Briefly, fractions of distillate with narrow boiling ranges were filtered through glass columns, 3 by $50 \mathrm{~cm}$, filled with gel of 40- to 200-mesh obtained from the Silica Gel Corporation, of Baltimore. The effect of the filtration was, by adsorption of the aromatic constituents, to lower somewhat the refractive index of the filtrate. When the index of the latter began to rise towards that of the material being filtered, the gel was considered saturated and was replaced with a fresh supply. On refiltering the oil, its refractive index remained unchanged. The index of the filtrate was now lower by 0.0001 than that of the material which had been treated with nitrating mixture. From these facts it was concluded that the aromatic constituents had been effectively removed. Adsorbed oil was recovered from the spent gel by displacing with water, either by leaching or distilling with steam. The results of the filtration are shown in table 1.

TABLE 1.-Volumes and refractive index of the distillation fractions before and after filtering through silica gel

\begin{tabular}{|c|c|c|c|c|c|c|c|}
\hline \multirow{3}{*}{$\begin{array}{c}\text { Boiling range at } 215 \mathrm{~mm} \\
\text { before filtering }\end{array}$} & \multicolumn{4}{|c|}{ Volume } & \multicolumn{3}{|c|}{ Refractive index } \\
\hline & \multirow{2}{*}{$\begin{array}{c}\text { Before } \\
\text { filtering }\end{array}$} & \multicolumn{2}{|c|}{ After filtering } & \multirow{2}{*}{$\begin{array}{l}\text { Lost by } \\
\text { filtering }\end{array}$} & \multirow{2}{*}{$\begin{array}{c}\text { Before } \\
\text { filtering, } \\
n_{D}^{25}\end{array}$} & \multicolumn{2}{|c|}{ After filtering } \\
\hline & & Filtrate & Adsorbed & & & $\begin{array}{c}\text { Filtrate, } \\
n_{D}^{25}\end{array}$ & $\begin{array}{c}\text { Adsorbed, } \\
n_{D}^{25}\end{array}$ \\
\hline $\begin{array}{l}9{ }^{\circ} \mathrm{C} \\
98 \text { to } 100.5 \\
100.5 \text { to } 102.0 \\
102.0 \text { to } 103.5\end{array}$ & $\begin{array}{l}\mathrm{mI} \\
5,230 \\
5,850 \\
5,660\end{array}$ & $\begin{array}{l}\mathrm{ml} \\
4,905 \\
5,380 \\
5,150\end{array}$ & ml $\begin{array}{r}210 \\
360 \\
460\end{array}$ & $\begin{array}{r}\mathrm{ml} \\
115 \\
110 \\
50\end{array}$ & $\begin{array}{l}1.415 \\
1.4125 \\
1.418\end{array}$ & $\begin{array}{l}\text { 1. } 4125 \\
1.4115 \\
1.416\end{array}$ & $\begin{array}{l}1.445 \\
1.425 \\
1.438\end{array}$ \\
\hline
\end{tabular}

The refractive index of the filtrate is shown in more detail in the graph of shaded lines in the upper part of figure 1. Both refractiveindex graphs show that, whereas each of the half-degree fractions

- All refractive indices recorded in this paper are for $n_{D}^{25}$ unless specified otherwise. Those obtained for the purpose of routine analysis were determined at $25^{\circ} \mathrm{C}$. The indices of the final purified products were determined at $20^{\circ} \mathrm{C}$. 
boiling below $100.5^{\circ} \mathrm{C}$ was filtered separately, the fractions boiling between 100.5 and $102^{\circ} \mathrm{C}$ and between 102 and $103.5^{\circ} \mathrm{C}$ were mixed before filtering. Arrows in the lower part of the figure show the boiling range of the mixtures; dotted lines in the upper part show

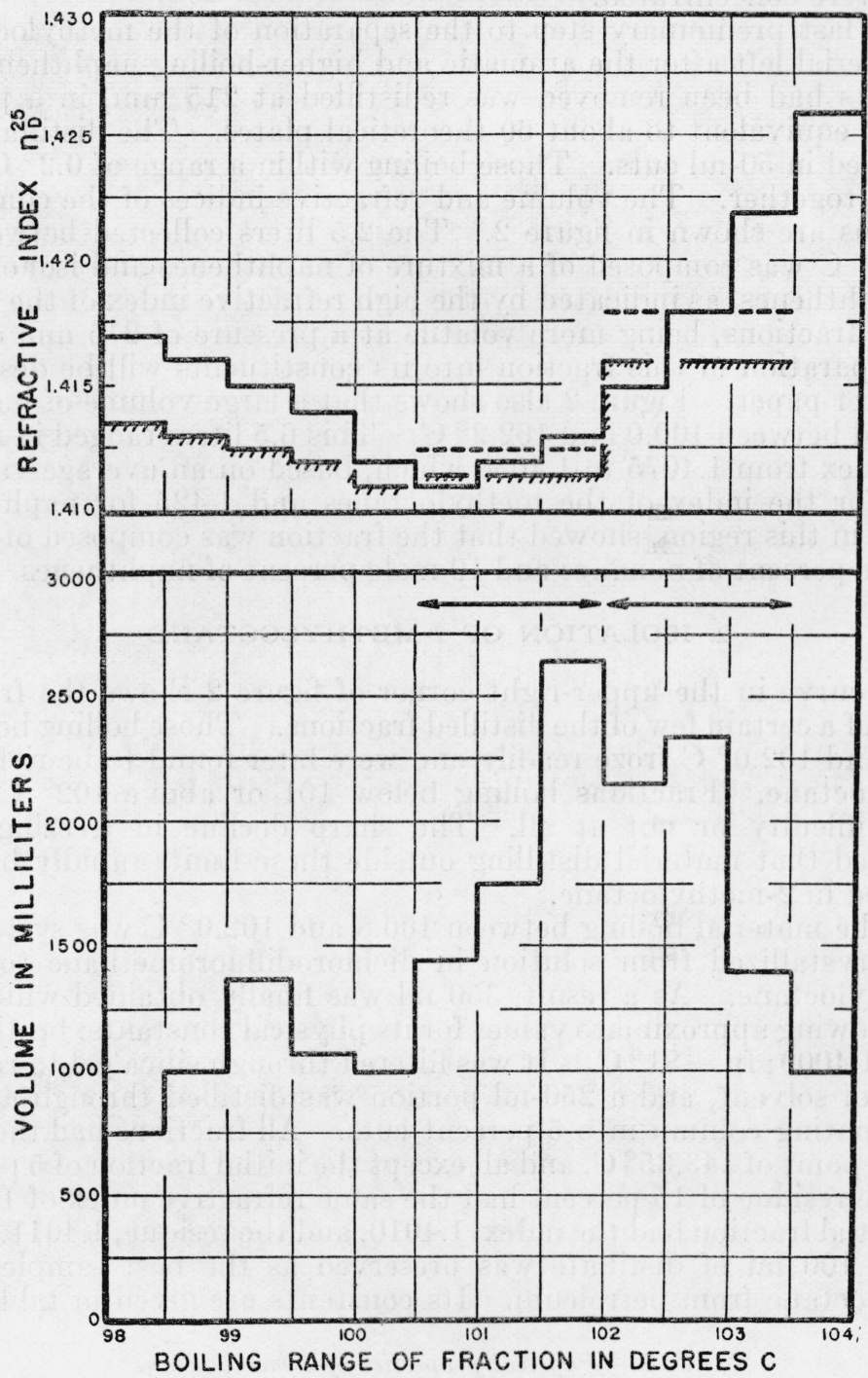

FIGURE 1.-Volumes and refractive indices of petroleum fractions, boiling between 98 and $104^{\circ} \mathrm{C}$ at $215 \mathrm{~mm}$, after extraction with sulphur dioxide and redistillation.

Lower graph, volume distribution with respect to boiling range; upper unshaded graph, refractive indices; upper shaded graph, refractive indices after filtration through silica gel. For explanation of arrows and dotted lines, see text.

their refractive indices before filtering. The mixing was done in order to expedite filtration of fractions requiring a subsequent distillation with glacial acetic acid to remove the higher-boiling morerefracting naphthenes present $[4,5]$. Of the total 15.5 liters of fil- 
trate, 10.5 liters which boiled between 100.5 and $103.5^{\circ} \mathrm{C}(142.5$ and $145.5^{\circ} \mathrm{C}$ at $760 \mathrm{~mm}$ ) was distilled with acetic acid with the result that about 4 liters, enriched in naphthenes boiling normally at $146^{\circ} \mathrm{C}$ or above, was displaced, leaving a 6.5-liter fraction in which isononanes alone were concentrated.

As a last preliminary step to the separation of the methyloctanes, all material left after the aromatic and higher-boiling naphthene constituents had been removed was redistilled at $215 \mathrm{~mm}$, in a packed column equivalent to about 60 theoretical plates. The distillate was recovered in $50-\mathrm{ml}$ cuts. Those boiling within a range of $0.2^{\circ} \mathrm{C}$ were poured together. The volume and refractive indices of the combined fractions are shown in figure 2. The 2.5 liters collected between 98 and $99^{\circ} \mathrm{C}$ was composed of a mixture of naphthenes and isononanes, the naphthenes, as indicated by the high refractive index of the lowerboiling fractions, being more volatile at a pressure of $215 \mathrm{~mm}$ of $\mathrm{Hg}$. The separation of this fraction into its constituents will be described in a later paper. Figure 2 also shows that a large volume of material distilled between 100.0 and $102.2^{\circ} \mathrm{C}$. This 6.5 liters ranged in refractive index from 1.4075 to 1.4050 which, based on an average value of 1.403 for the index of the methyloctanes and 1.425 for naphthenes boiling in this region, showed that the fraction was composed of about 90 mole percent of nonanes and 10 mole percent of naphthenes.

\section{ISOLATION OF 2-METHYLOCTANE}

The curve in the upper-right corner of figure 2 shows the freezing points of a certain few of the distilled fractions. Those boiling between 101.0 and $102.0^{\circ} \mathrm{C}$ froze readily and were later found to be rich in 2methyloctane. Fractions boiling below 101 or above $102^{\circ} \mathrm{C}$ froze with difficulty or not at all. The sharp decline in freezing point indicated that material distilling outside these limits rapidly became depleted in 2-methyloctane.

All the material boiling between 100.8 and $102.0^{\circ} \mathrm{C}$ was systematically crystallized from solution in dichlorodifluoromethane to yield 2-methyloctane. As a result, $350 \mathrm{ml}$ was finally obtained which had the following approximate values for its physical constants: bp $143.35^{\circ}$ $\mathrm{C} ; n_{D}^{25} 1.4009 ; \mathrm{fp}-81^{\circ} \mathrm{C}$. It was filtered through silica gel to remove traces of solvent, and a $250-\mathrm{ml}$ portion was distilled through a small fractionating column into 5-percent cuts. All fractions had the same boiling point of $143.35^{\circ} \mathrm{C}$, and all except the initial fraction of 5 percent and the residue of 15 percent had the same refractive index of 1.4008 . The initial fraction had the index, 1.4010, and the residue, 1.4011. The middle $100 \mathrm{ml}$ of distillate was preserved as the best sample of 2methyloctane from petroleum. Its constants are given in table 2.

TABLE 2.-Physical properties of 2-methyloctane

\begin{tabular}{|c|c|c|c|c|c|c|}
\hline Sample & $\begin{array}{c}\text { Normal } \\
\text { boiling } \\
\text { point }\end{array}$ & $\begin{array}{l}\text { Freezing } \\
\text { point }\end{array}$ & $\begin{array}{c}\text { Specific } \\
\text { gravity, } \\
\boldsymbol{d}_{4}^{20}\end{array}$ & $\left|\begin{array}{c}\text { Refrac- } \\
\text { tive index } \\
n_{D}^{20}\end{array}\right|$ & $\begin{array}{l}\text { est in ani- } \\
\text { line }\end{array}$ & $\begin{array}{l}\text { Combustion } \\
\text { analysis }\end{array}$ \\
\hline $\begin{array}{l}\text { From Oklahoma petroleum. } \\
\text { Whitmore and Southgate... }\end{array}$ & $\begin{array}{l}{ }^{\circ} \mathrm{C} \\
\mathrm{s} 143.255 \\
\mathrm{e} 142.80\end{array}$ & $\begin{array}{c}{ }^{\circ} \mathrm{C} \\
-80.49 \pm .02 \\
.-80\end{array}$ & $\begin{aligned} & \text { b } 0.7134 \\
& \text { c. } 7107\end{aligned}$ & $\begin{array}{ll} & 1.4032 \\
\cdot & 1.40285\end{array}$ & $\stackrel{\circ}{\circ} \mathrm{C}$ & $\begin{array}{l}\text { Moles } \mathrm{H}_{2} \mathrm{O} \\
\text { Moles } \mathrm{CO}_{2} \\
1.1115 \pm .0005\end{array}$ \\
\hline
\end{tabular}

a Determined by E. R. Smith of this Bureau. $d t / d p=0.0495$.

- Determined by the Division of Weights and Measures of this Bureau.

- Private communication from H. A. Southgate and F. C. Whitmore, Pennsylvania State College. 


\section{ISOLATION OF 3-METHYLOCTANE}

After a process of interlocking distillation with crystallization to remove effectively the 2-methyloctane, all mother liquors which

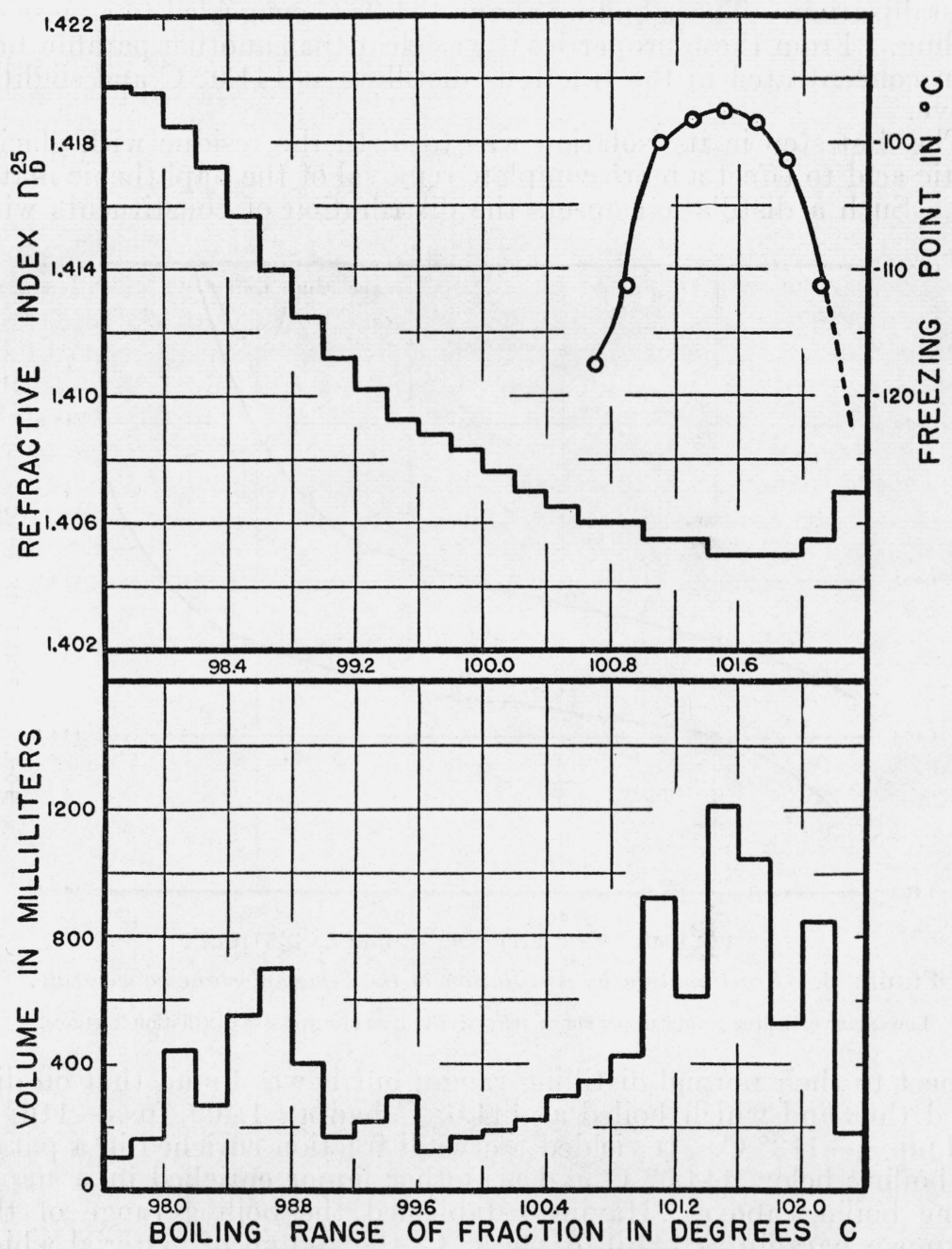

FIGURE 2.-Volumes, refractive indices, and freezing points of redistilled petroleum fractions after removing aromatic and higher-boiling naphthene hydrocarbons.

Lower graph, volume distribution with respect to boiling range at 215 millimeters; upper graph, refractive indices; curve at upper right, freezing points

boiled above $143.6^{\circ} \mathrm{C}$, together with the distillation stock boiling up to $144.4^{\circ} \mathrm{C}\left(102.4^{\circ} \mathrm{C}\right.$ at $\left.215 \mathrm{~mm}\right)$, were redistilled into $50-\mathrm{ml}$ fractions. About $500 \mathrm{ml}$ of distillate and $600 \mathrm{ml}$ of still residues were obtained. The distillate boiled between 143.8 and $144.2^{\circ} \mathrm{C}$, ranged in refractive index from 1.404 to 1.405 and, from combustion analysis, contained 5 
percent of naphthenes. ${ }^{6}$ The residue boiled at $144.6^{\circ} \mathrm{C}$ and contained about 20 percent of naphthenes. Fractions boiling at $144.0^{\circ} \mathrm{C}$ froze at $-117^{\circ} \mathrm{C}$ but did not fractionate on crystallization. Those boiling below $144.0^{\circ} \mathrm{C}$ froze above $-117^{\circ} \mathrm{C}$ and yielded 2-methyloctane on crystallization. Those boiling above $144.0^{\circ} \mathrm{C}$ congealed to a glass on cooling. From these properties it was clear that another paraffin had been concentrated in the fractions distilling at $144.0^{\circ} \mathrm{C}$ and slightly above.

The first step in its isolation was to distil the residue with glacial acetic acid to effect a more complete removal of the naphthenic material. Such a distillation upsets the distribution of constituents with

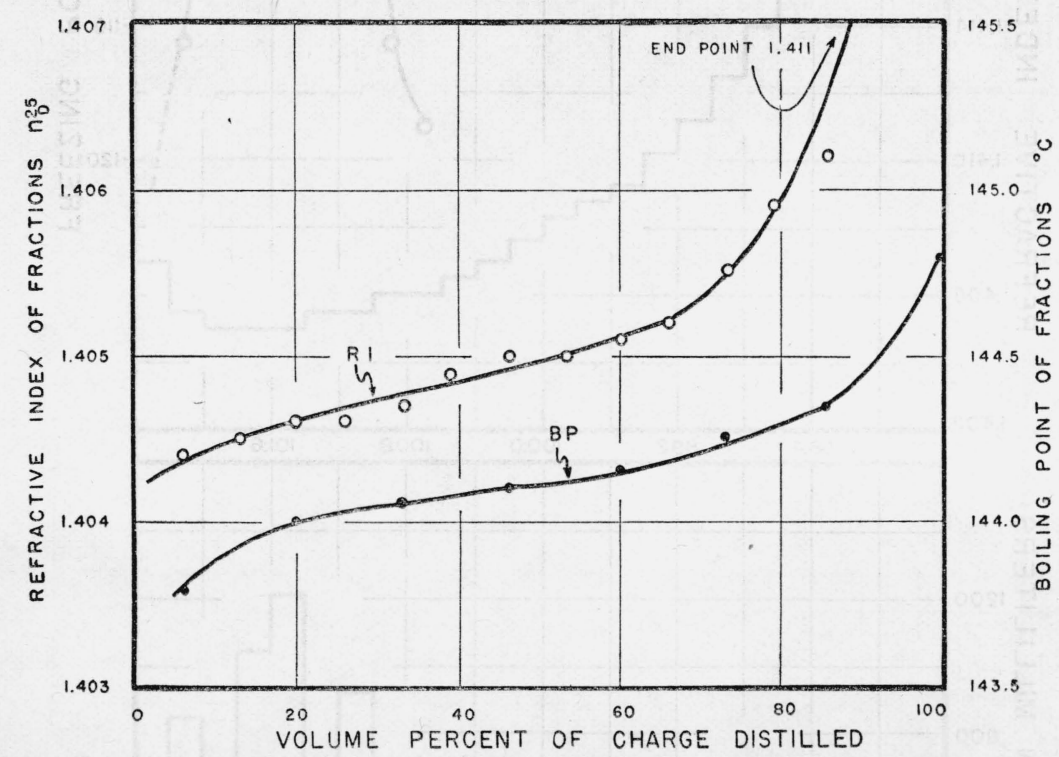

FIgURE 3.-Fractionation by distillation of the 3-methyloctane concentrate.

Lower curve, boiling points; upper curve, refractive indices of successive distillation fractions.

respect to their normal distilling range; but it was found that oil distilled thus and which boiled at $144.6^{\circ} \mathrm{C}$ had $n=1.409, \mathrm{fp}=-116^{\circ} \mathrm{C}$ and $\mathrm{mp}=-112^{\circ} \mathrm{C}$. It yielded a crystal fraction enriched in a paraffin boiling below $144.5^{\circ} \mathrm{C}$ and a mother liquor enriched in a naphthene boiling above. Having established the boiling range of the unknown paraffin as 144.0 to $144.5^{\circ} \mathrm{C}$, the $800 \mathrm{ml}$ of material which boiled within these limits was carefully fractionated at atmospheric pressure. The results are shown in figure 3 . The cooling and warming curve of a $50-\mathrm{ml}$ cut, taken after 60 percent of the charge had been distilled, is shown in curve $I$ of figure 4 . The cut boiled at $144.2^{\circ} \mathrm{C}$, had nearly the formula $\mathrm{C}_{9} \mathrm{H}_{20}$, a refractive index of 1.4052 , froze at $-114.0^{\circ} \mathrm{C}$ and melted at $-111.5^{\circ} \mathrm{C}$. A mixture of the sample with an equal amount of 2 -methyloctane boiled at $143.85^{\circ} \mathrm{C}$. Its cooling and warming curves are shown as curve $I I$ in figure 4 . The initial freezing point of $-90^{\circ} \mathrm{C}$ is that of excess 2 -methyloctane.

6 The combustion analyses of the paraffin-naphthene hydrocarbon mixtures studied in this work are made by determining the ratio of moles $\mathrm{H}_{2} \mathrm{O} / \mathrm{moles} \mathrm{CO}_{2}$ with an average deviation of \pm 0.0005 . This enables one to express the composition of the mixture in moles percent of naphthenes and nonanes to within about 0.5 percent. For the method of combustion used, see Rossini, BS J. Research 8, 121 (1932) RP405. 
The eutectic halt occurred at $-114.5^{\circ} \mathrm{C}$. Extrapolation of the melting curve indicated that the eutectic point was near $-113.5^{\circ} \mathrm{C}$. A property of the distilled fraction was its tendency to undercool greatly before crystallizing. The undercooling of $15^{\circ} \mathrm{C}$ and the prolonged induction period of crystallizing are typical of all of the fractions shown in figure 3. The degree of undercooling could be diminished somewhat by seeding with crystals. ${ }^{7}$ In fact, fractions which boiled between 144.0 and $144.1^{\circ} \mathrm{C}$ could be crystallized only when seeded. Material boiling near $144.0^{\circ} \mathrm{C}$ was apparently eutectic in composition as indicated by a single temperature halt near $-113.5^{\circ} \mathrm{C}$ in both the cooling and warming curves.

Systematic crystallization from solution in dichlorodifluoromethane of all distillate boiling above $144.1^{\circ} \mathrm{C}$ finally yielded a sample of the

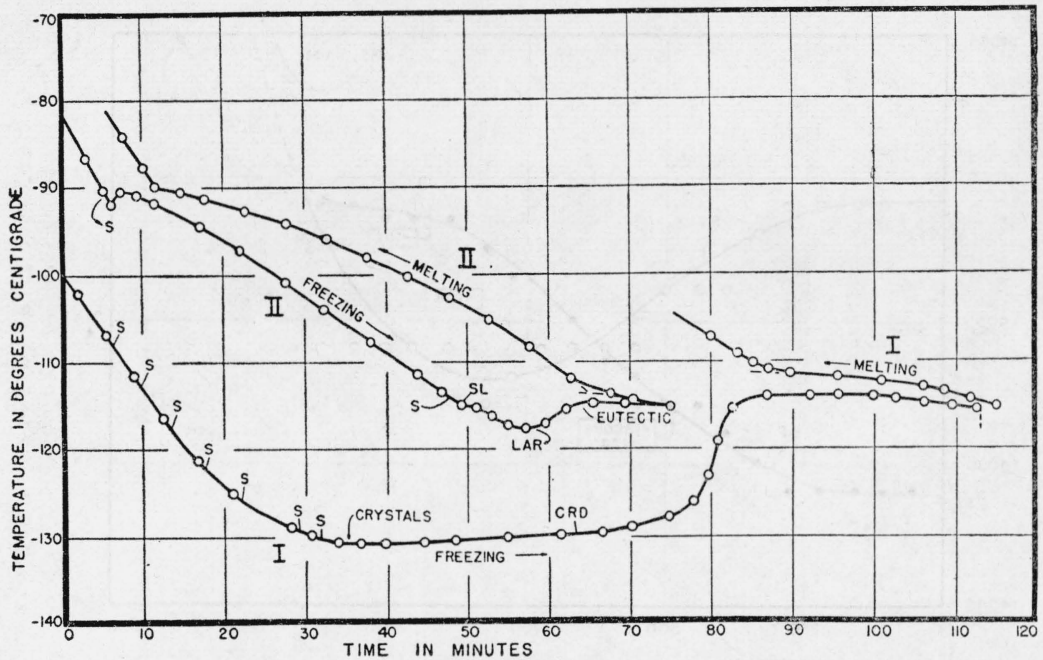

FIgURE 4.-Cooling and warming curves of mixtures of 2- and 3-methyloctane.

Curve $I$, for a distillation fraction boiling at $144.2^{\circ} \mathrm{C}$; curve $I I$, for a mixture of equal volumes of the sample used for curve $I$ and of 2 -methyloctane. $S$, stirred with a cold rod to induce crystallization; $S L$, stirrer labored; $L A R$, liquid air removed; $C R D$ cooling rate reduced.

nonane which, when freed from solvent, was of sufficient purity to identify it from its properties as 3-methyloctane. See table 3.

TABLE 3.-Physical properties of 3-methyloctane

\begin{tabular}{|c|c|c|c|c|c|c|}
\hline Sample & $\begin{array}{l}\text { Normal } \\
\text { boiling } \\
\text { point }\end{array}$ & Melting point & $\begin{array}{c}\text { Specific } \\
\text { gravity, } \\
d_{1}^{20}\end{array}$ & $\begin{array}{c}\text { Refrac- } \\
\text { tive } \\
\text { index, } \\
n_{D}{ }^{2}\end{array}$ & $\begin{array}{l}\text { est in ant- } \\
\text { line }\end{array}$ & $\begin{array}{l}\text { Combustion } \\
\text { analysis }\end{array}$ \\
\hline $\begin{array}{l}\text { From Oklahoma petroleum. } \\
\text { Synthetic }(l-\text { form })\end{array}$ & $\begin{array}{c}{ }^{\circ} \mathrm{C} \\
\stackrel{1}{144.180} \\
\cdot 143 \text { to } 144\end{array}$ & ${ }^{\circ} \mathrm{C}$ & $\begin{array}{l}\text { b } 0.7210 \\
\text { c d. } 720\end{array}$ & $\begin{array}{r}1.4065 \\
\text { c } 1.4075\end{array}$ & $\stackrel{\circ}{\circ} \mathrm{C}$ & $\begin{array}{l}\frac{\text { Moles } \mathrm{H}_{2} \mathrm{O}}{\text { Moles } \mathrm{CO}_{2}} \\
1.1095 \pm .0004\end{array}$ \\
\hline
\end{tabular}

a Determined by E. R. Smith of this Bureau. $d t / d p=0.0495$.

Determined by the Division of Weights and Measures of this Bureau.

- Levene and Marker, J. Biol. Chem. 91, 101 (1931).

d Calculated from value given for $27^{\circ} \mathrm{C}$.

- Calculated from value given for $25^{\circ} \mathrm{C}$.

${ }^{7}$ Crystals for seeding were obtained by cooling a small portion of the fraction mixed with dichlorodifluoromethane to reduce its viscosity. 


\section{ISOLATION OF 4-METHYLOCTANE}

Figure 5 shows the results of distilling the lower-boiling residues from the fractional crystallization of 2-methyloctane. The lower curve in the figure reveals two boiling-point plateaus, one at $142.4^{\circ} \mathrm{C}$, the other near $143.4^{\circ}$. Freezing points of fractions boiling at these temperatures are shown by the numbers in the boxes. Material boiling at the higher temperature crystallized readily to yield 2-methyloctane. Fractions boiling at $142.4^{\circ} \mathrm{C}$ would freeze while those boiling near $142.7^{\circ} \mathrm{C}$ would not. They became very viscous at $-130^{\circ} \mathrm{C}$ and congealed to glasses on further cooling. The constant-boiling nature, the freezing behavior, and low refractive index of the distillate which boiled at $142.4^{\circ} \mathrm{C}$ indicated that it was a concentrate of another paraffin hydrocarbon. To obtain more of the compound, all distilla-

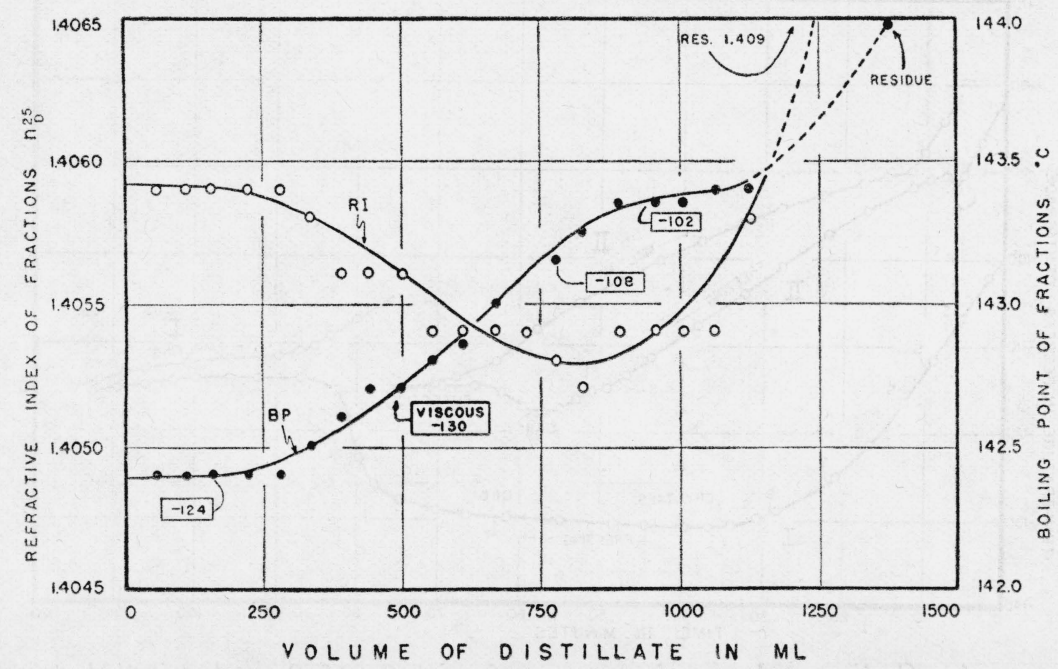

FIGURE 5.-Fractionation by distillation of residues obtained from crystallizing the 2-methyloctane concentrate.

Black circles indicate boiling points, white circles indicate refractive indices of successive distillation fractions. Numbers in the boxes indicate freezing points.

tion stock boiling normally between 141 and $143^{\circ} \mathrm{C}$ was first distilled at $215 \mathrm{~mm}$ to remove the lower-boiling naphthenes. Subsequently, the material obtained by this procedure which boiled between 142 and $143^{\circ} \mathrm{C}$ was distilled with acetic acid to separate higher boiling naphthenes. As a result, 2 liters was obtained which boiled within the range 141.5 to $143.4^{\circ} \mathrm{C}$. The material ranged in refractive index from 1.410 to 1.404 and, from combustion analysis, varied in naphthene content from 20 to 5 mole percent. Assuming the refractive index of the naphthenic material to be 1.425 , the paraffin base of the distillate was calculated to vary in refractive index from 1.406 to 1.403 . The range could be explained by assuming that the detected paraffin boiling near $142.4^{\circ} \mathrm{C}$ was mixed with a lower-boiling paraffin having a higher refractive index and with 2-methyloctane with a lower index. Further analysis proved this assumption to be correct. A systematic distillation at normal pressure of the 2-liter fraction yielded at last 1 liter of distillate boiling between 142.0 and $143.0^{\circ} \mathrm{C}$. The results of the final 
distillation are shown in figure 6 . The boiling-point curve shows, as did the curve in figure 5, a region of minimum slope centering on $142.4^{\circ}$ C. Apparently the distillation did not improve the concentration of the detected compound. It did reveal, none the less, that the compound was present in limited quantities and that the composition of the material, which originally distilled between 141.5 and $143^{\circ} \mathrm{C}$, was quite complex. Additional evidence indicated that the material contained at least five compounds. Of the final distillate, $250 \mathrm{ml}$, representing the middle portion, was subjected to further fractionation by crystallization. The $50-\mathrm{ml}$ distillation cuts comprising this fraction contained on the average 10 mole percent of naphthenes and probably a greater amount of paraffinic constituents other than the one

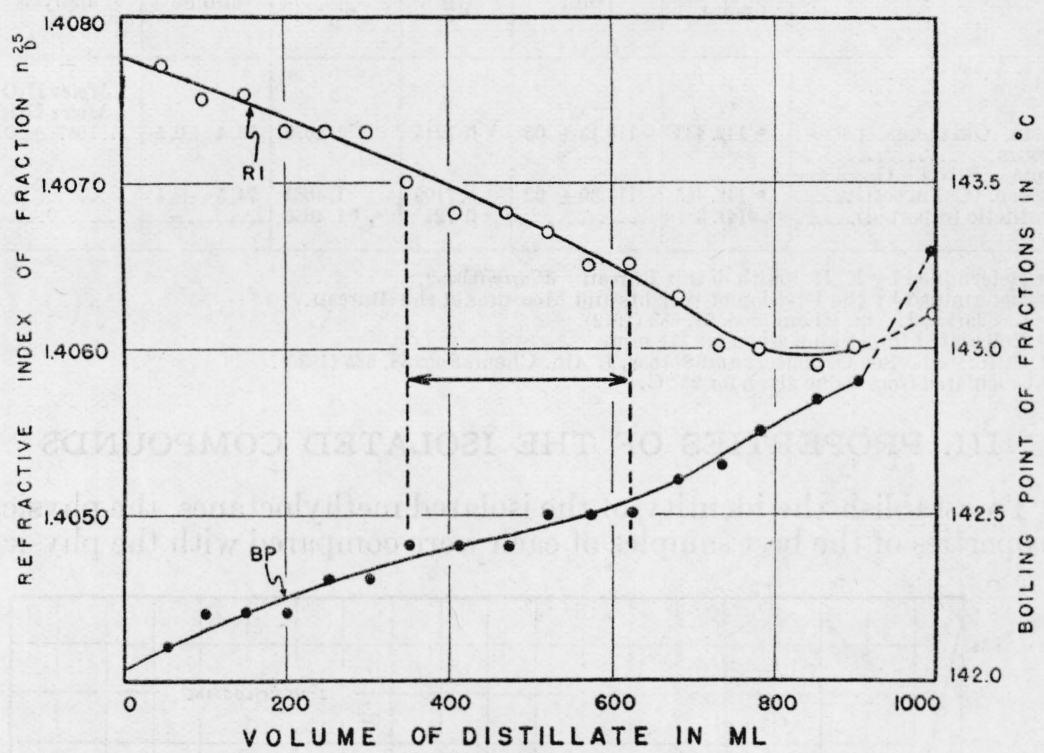

FigURE 6.-Fractionation by distillation of the 4-methyloctane concentrate.

Lower curve, boiling points; upper curve, refractive indices of successive distillation fractions. The arrow indicates the portion of the distillate subsequently subjected to fractional crystallization.

being concentrated. The cuts were, however, largely composed of the desired component. None of them showed a normal cooling behavior. Between -125 and $-130^{\circ} \mathrm{C}$ each became suddenly viscous and thereupon produced a temperature halt which in all respects resembled true crystallizing behavior, with the exception that no definitely visible crystals were formed. At this stage the samples were faintly turbid and had the consistency of stiff glue.

Crystallization of the $250-\mathrm{ml}$ fraction from a solution in propane and methane by the method described by Leslie [6] yielded a 70-ml sample of hydrocarbon which, when freed from solvent, boiled at $142.4^{\circ} \mathrm{C}$, had a refractive index of 1.4055 , and melted at $-119^{\circ} \mathrm{C}$. By combustion it was found to be composed of 5.7 mole percent of naphthenes and 94.3 percent of isononanes. Of the latter, 4-methyloctane (see table 4) and 3-ethylheptane ${ }^{8}$ boil, respectively, at

\footnotetext{
${ }^{8}$ A sample of 3 -ethylheptane was lent to us by F. C. Whitmore and H. P. Orem, of the Pennsylvania State
} College. 
142.5 and $143.1^{\circ} \mathrm{C}$. Since the petroleum fraction had a lower boiling point and a lower refractive index than 3-ethylheptane, and since there is no evidence that this petroleum contains 3-ethylheptane in more than negligible amounts, if at all, it was concluded that the sample of petroleum in question was a concentrate of 4-methyloctane. Confirmatory evidence of this was obtained from the slight elevation of the melting point when 5 percent of synthetic 4-methyloctane was added to the sample.

TABLE 4.-Properties of 4-methyloctane

\begin{tabular}{|c|c|c|c|c|c|c|}
\hline Sample & $\begin{array}{l}\text { Normal } \\
\text { boiling } \\
\text { point }\end{array}$ & $\begin{array}{l}\text { Melting } \\
\text { point }\end{array}$ & $\begin{array}{c}\text { Specific } \\
\text { gravity, } \\
d_{4}^{20}\end{array}$ & $\begin{array}{c}\text { Refractive } \\
\text { index, } \\
n_{D}^{20}\end{array}$ & $\begin{array}{l}\text { cst in } \\
\text { aniline }\end{array}$ & $\begin{array}{l}\text { Combustion } \\
\text { analysis }\end{array}$ \\
\hline $\begin{array}{l}\text { From Oklahoma petro- } \\
\text { leum }\end{array}$ & a ${ }^{\circ} \mathrm{C}$ & $\begin{array}{l}{ }^{\circ} \mathrm{C} \\
-119.13 \pm .05\end{array}$ & • 0.7245 & 1.4078 & $73.4 \pm 0.5$ & $\begin{array}{c}\text { Moles } \mathrm{H}_{2} \mathrm{O} \\
\text { Moles } \mathrm{CO}_{2} \\
1.1047 \pm .0005\end{array}$ \\
\hline $\begin{array}{l}\text { From Ethyl Gasoline } \\
\text { Corp. (Calingaert) } \\
\text { Synthetic (reported) }\end{array}$ & $\begin{array}{l}\text { a } 142.485 \\
\text { c, d141.3 }\end{array}$ & $-113.30 \pm .02$ & $\begin{aligned} \text { b. } 7199 \\
\cdot 0.721\end{aligned}$ & $\begin{aligned} & 1.4061 \\
& \circ, \ell 1.4050\end{aligned}$ & $74.5 \pm .5$ & \\
\hline
\end{tabular}

a Determined by E. R. Smith of this Bureau. $d t / d p=0.0492$.

b Determined by the Division of Weights and Measures of this Bureau.

c L. Clarke, J. Am. Chem. Soc. 34, 683 (1912).

d Calculated from value gi ven for $771 \mathrm{~mm}$.

e Estimated. See Calingaert and Soroos, J. Am. Chem. Soc. 58, 635 (1936).

${ }^{i}$ Calculated from value given for $25^{\circ} \mathrm{C}$.

\section{PROPERTIES OF THE ISOLATED COMPOUNDS}

To establish the identity of the isolated methyloctanes, the physical properties of the best samples of each were compared with the physical

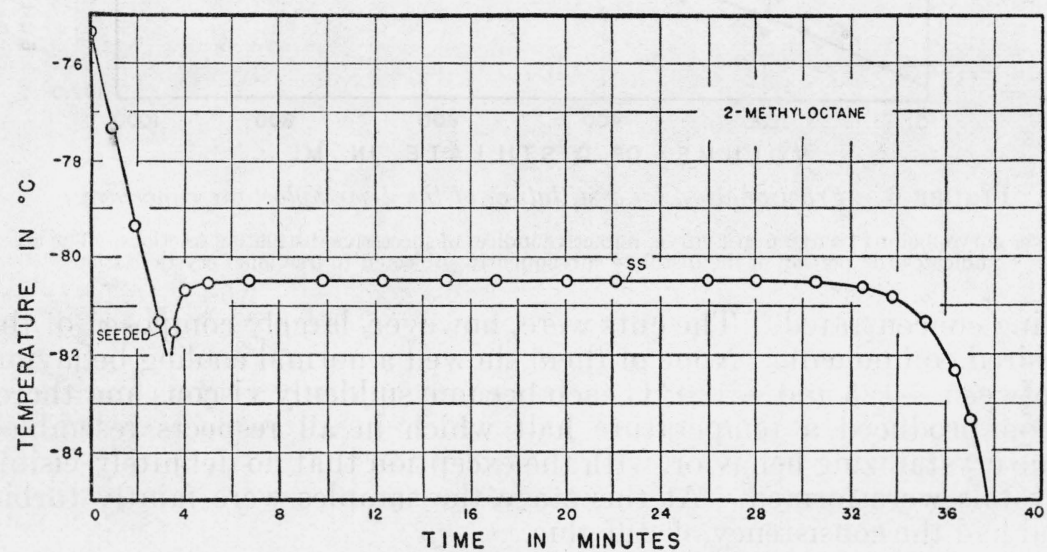

FIGURE 7.-Time-temperature cooling curve of the 2-methyloctane isolated from petroleum.

properties reported for the corresponding synthetic compound. In cases where the reported densities showed large discrepancies, values were computed from the molecular volume data correlated by Calingaert and Hladky [7]. Results of the comparisons are given in tables 2,3 , and 4 . The errors indicated are average deviations. A similar comparison was made, in the case of 4-methyloctane, with a sample 
of high purity lent to us by Dr. Calingaert of the Ethyl Gasoline Corporation in Detroit (see table 4). Ebulliometric tests of purity were made on the samples by E. R. Smith of the Physical Chemistry

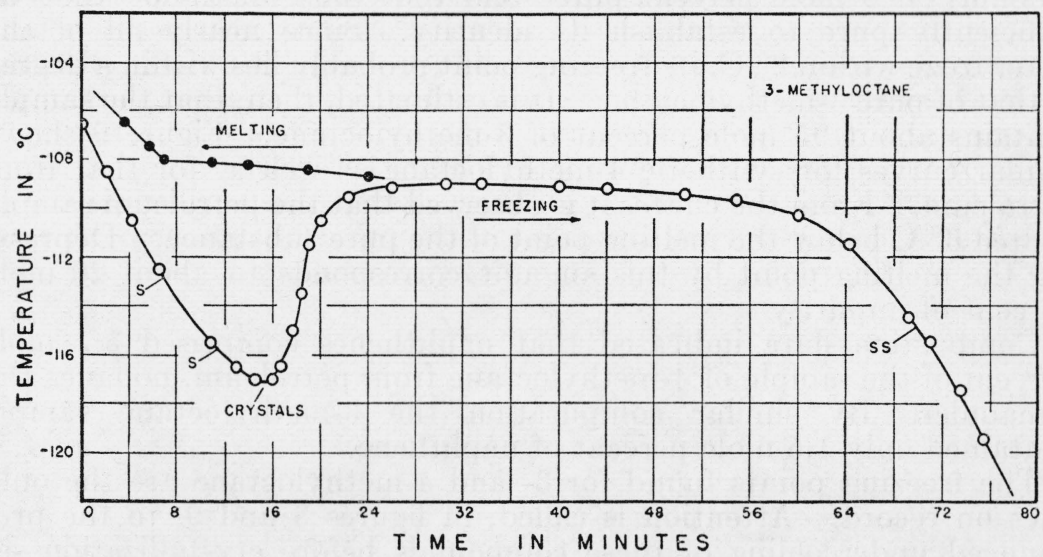

FIGURE 8.-Time-temperature cooling and warming curves of the 3-methyloctane isolated from petroleum.

$S$, seeded with crystals; SS, stirrer stopped.

Section of this Bureau, who also determined the boiling points. In each case the measurements were made in a standard Swiętosławski differential ebulliometer [8] in the manner described by Wojciechowski [9]. The tests were based on $\Delta t$, the difference between the boiling

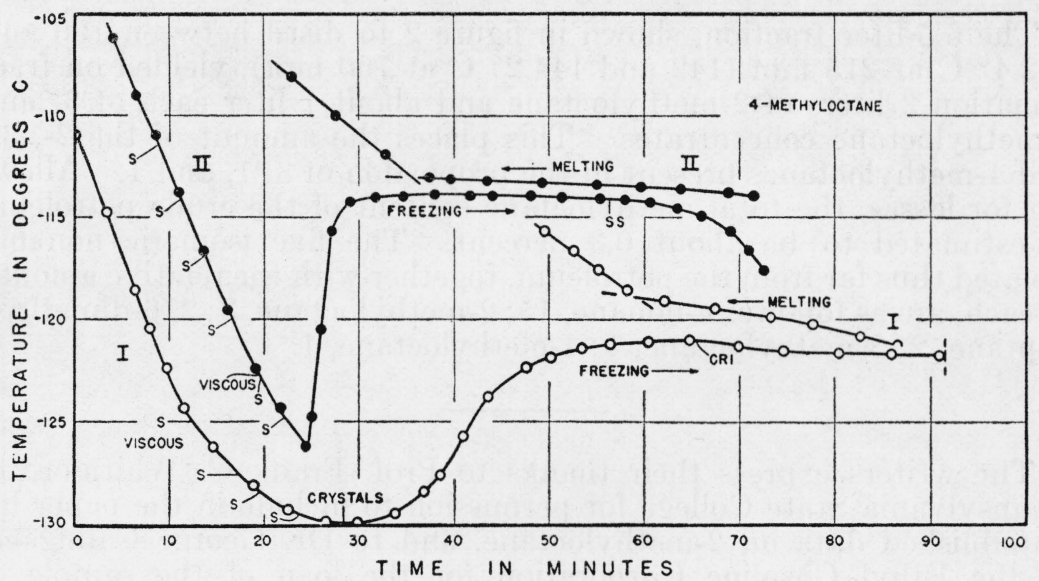

FIGURE 9.-Time-temperature cooling and warming curves of 4-methyloctane.

Curve I, from petroleum; curve $I I$, from the Ethyl Gasoline Corporation. $S$, seeded with crystals; $C R I$, cooling rate increased, SS, stirrer stopped.

and condensation points. Although the magnitude of the difference depends upon the nature of the impurity as well as the amount, a relative idea of purity is thus obtained. The values found for $\Delta t$ were all small, $0.015^{\circ} \mathrm{C}$ for 2-methyloctane, $0.028^{\circ} \mathrm{C}$ for 3-methyloctane, and $0.036^{\circ} \mathrm{C}$ for 4-methyloctane. 
As a further test of purity, the behavior of the samples during cooling and warming was observed. The freezing and melting curves shown in figures 7 and 8 indicate that the sample of 2-methyloctane was probably 99.9 mole percent pure ${ }^{9}$ and that the 3 -methyloctane was sufficiently pure to establish its identity. Since nearly all of the latter froze within $2^{\circ} \mathrm{C}$, its freezing point probably lies within a degree of that of pure 3-methyloctane. It is estimated, then, that the sample contains about 95 mole percent of 3 -methyloctane. Figure 9 shows similar curves for synthetic 4-methyloctane as well as for that from petroleum. From the curves it is observed that the petroleum sample melted $6^{\circ} \mathrm{C}$ below the melting point of the pure substance. Depressing the melting point by this amount corresponds to about 20 mole percent of impurity.

Combustion data indicated that naphthenes comprised 5.7 mole percent of the sample of 4-methyloctane from petroleum, nonanes the remainder. By similar computation the 3-methyloctane sample contained only 1.5 mole percent of naphthene.

The freezing points found for 3- and 4-methyloctane are the only ones on record. Attention is called, in figures 8 and 9 , to the pronounced undercooling of these compounds before crystallization set in. Parks, Thomas, and Light associate the phenomenon with optical isomerism [10]. These authors state that in $d l$ mixtures, especially $d l$ mixtures of hydrocarbons, the presence of two varieties of molecules with equal intermolecular forces strongly militates against crystallization.

\section{CONTENT OF THE METHYLOCTANES IN THE PETROLEUM}

The 6.5-liter fraction, shown in figure 2 to distil between 100 and $102.4^{\circ} \mathrm{C}$ at $215 \mathrm{~mm}\left(142\right.$ and $144.2^{\circ} \mathrm{C}$ at $760 \mathrm{~mm}$ ), yielded on fractionation 3 liters of 2-methyloctane and about 1 liter each of 3- and 4-methyloctane concentrates. This places the amount of the 2-, 3-, and 4-methyloctanes present in the proportion of 3,1 , and 1 . Allowing for losses, the total methyloctane content of the crude petroleum is estimated to be about 0.3 percent. The five isomeric nonanes isolated thus far from the petroleum, together with the relative amount of each, are as follows: $n$-nonane, $15 ; 2$-methyloctane, $3 ; 2,6$-dimethylheptane, 2; 3-methyloctane, 1; 4-methyloctane, 1.

The writers express their thanks to Prof. Frank C. Whitmore of Pennsylvania State College for permission to include in the paper his unpublished data on 2-methyloctane, and to Dr. George Calingaert of the Ethyl Gasoline Corporation for the loan of the sample of synthetic 4-methyloctane. Grateful acknowledgment is also made to Prof. M. R. Fenske and H. P. Orem of Pennsylvania State College and to Dr. F. D. Rossini of the National Bureau of Standards, for their aid in placing valuable data on the isomeric nonanes at our disposal, and to S. T. Schicktanz, F. W. Rose, Jr., and other members of the staff of Project 6 for superintending the distillation of the petroleum.

${ }^{\circ}$ Calculated from a computed depression of the freezing point of $0.01^{\circ} \mathrm{C}$ and an estimated heat of fusion of $4.0 \pm 0.5 \mathrm{Kcal} / \mathrm{mole}$. 


\section{REFERENCES}

[1] J. D. White and F. W. Rose, Jr. BS J. Research 9, 711 (1932) RP501.

[2] C. O. Tongberg, M. R. Fenske, and J. E. Nickels, Ind. Eng. Chem. 29, 70 (1937).

[3] B. J. Mair and J. D. White, J. Research NBS 15, 59 (1935) RP809.

[4] S. T. Schicktanz, J. Research NBS 18, 129 (1937) RP967.

[5] J. D. White and F. W. Rose, Jr., J. Research NBS 1\%, 943 (1936) RP955.

[6] R. T. Leslie, BS J. Research 10, 609 (1933) RP552.

[7] G. Calingaert and J. W. Hladky, J. Am. Chem. Soc. 58, 153 (1936).

[8] W. Swietosławski, J. Phys. Chem. 38, 1169 (1934).

[9] M. Wojciechowski, J. Research NBS 1\%, 453 (1936) RP921.

[10] G. S. Parks, S. B. Thomas, and D. W. Light, J. Chem. Phys. 4, 64 (1936).

Washington, July 17, 1937. 